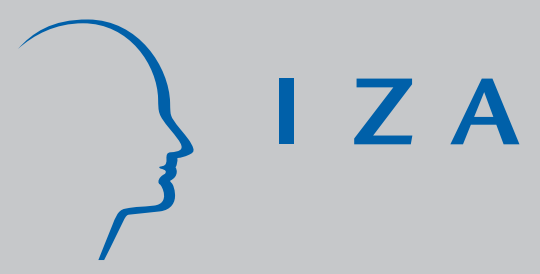

IZADP No. 3289

Do Reservation Wages Really Decline?

Some International Evidence on the Determinants of Reservation Wages

J ohn T. Addison

Mário Centeno

Pedro Portugal

J anuary 2008 


\title{
Do Reservation Wages Really Decline? Some International Evidence on the Determinants of Reservation Wages
}

\author{
John T. Addison \\ Queen's University Belfast \\ and IZA \\ Mário Centeno \\ Banco de Portugal \\ and Universidade Técnica de Lisboa \\ Pedro Portugal \\ Banco de Portugal, Universidade Nova de Lisboa \\ and IZA
}

Discussion Paper No. 3289

January 2008

IZA

P.O. Box 7240

53072 Bonn

Germany

Phone: +49-228-3894-0

Fax: +49-228-3894-180

E-mail: iza@iza.org

\begin{abstract}
Any opinions expressed here are those of the author(s) and not those of IZA. Research published in this series may include views on policy, but the institute itself takes no institutional policy positions.

The Institute for the Study of Labor (IZA) in Bonn is a local and virtual international research center and a place of communication between science, politics and business. IZA is an independent nonprofit organization supported by Deutsche Post World Net. The center is associated with the University of Bonn and offers a stimulating research environment through its international network, workshops and conferences, data service, project support, research visits and doctoral program. IZA engages in (i) original and internationally competitive research in all fields of labor economics, (ii) development of policy concepts, and (iii) dissemination of research results and concepts to the interested public.
\end{abstract}

IZA Discussion Papers often represent preliminary work and are circulated to encourage discussion. Citation of such a paper should account for its provisional character. A revised version may be available directly from the author. 
IZA Discussion Paper No. 3289

January 2008

\section{ABSTRACT}

\section{Do Reservation Wages Really Decline? Some International Evidence on the Determinants of Reservation Wages}

Using cross-country data, we investigate the determinants of reservation wages and their course over the jobless spell. Higher unemployment benefits lead to higher reservation wages. Further, again consistent with the basic search model, repeated observations on the same individual provide scant evidence of declining reservation wages.

JEL Classification: J64, J65

Keywords: reservation wages, probability of reemployment, unemployment benefits, arrival rate of job offers

Corresponding author:

John T. Addison

Management School

Queen's University Belfast

Belfast BT7 1NN

Northern Ireland

United Kingdom

E-mail: j.addison@qub.ac.uk 


\section{Introduction}

Reservation wages play a key role in search theory, wherein optimal job search implies the reservation wage property and the optimal stopping rule. Despite its key role in theory, however, most empirical search studies have been conducted in the absence of reservation wage data, at best identifying this basic search-theoretic element through theoretical and auxiliary restrictions (e.g. Bloemen and Stancanelli, 2001). For their part, the much sparser group of studies with direct evidence on reservation wages (surveyed in Devine and Kiefer, 1991) have largely been based on single survey responses, and typically contain little retrospective information about employment or income histories. And in neither case is there comparative evidence.

The present exercise is exploratory. We deploy a unique cross-country data set that combines survey information on the lowest wages that unemployed respondents are willing to accept with detailed information on their employment and income histories to examine three key features of the stationary job search model. First, we examine the association between reservation wages and unemployment benefits. Second, we provide the first evidence of which we are aware on the role of the arrival rate of job offers in elevating reservation wages. Finally, exploiting the longitudinal capacity of our data set, we determine whether reservation wages decline over the jobless spell.

\section{Reservation Wages: The Associations Suggested by Theory}

Assuming income-maximizing workers, infinite lives, unemployment benefits and jobs (once accepted), sampling without recall, wage offers that are independent realizations from a known wage offer distribution and received according to a Poisson process with parameter $\delta$, the reservation wage rate can be written:

$$
w^{r}=b+\frac{\delta}{\rho} \int_{w^{r}}^{\infty}\left(w-w^{r}\right) \partial F(w),
$$


where $b$ is the (constant) amount of unemployment benefits net of any search costs, $\rho$ is the discount rate, $w$ is the wage offer, and $F(w)$ is the cumulative wage distribution (Mortensen, 1977). Evaluating the integral and rearranging terms gives

$$
\left(w^{r}-b\right) \rho=\left[E_{w}\left(w \mid w \geq w^{r}\right)-w^{r}\right]\left[1-F\left(w^{r}\right)\right] \delta,
$$

which makes more transparent the role of the reservation wage in equating the marginal costs and benefits of continued search.

Familiarly, then, changes in the independent variables affect either the marginal costs or benefits of additional search, producing offsetting changes in the reservation wage. Specifically, the derivatives of the reservation wage with respect to unemployment benefits, the arrival rate of job offers, and the mean of the wage offer distribution are all positive, while the derivative of the reservation wage with respect to the discount rate is negative.

The central assumption of the model is that reservation wages are time invariant because the present discounted value of accepting a job offer is continuous and increasing in $w$, and because the present discounted value of unemployed search does not depend on any particular offered wage, only the distribution.

\section{Data}

Our data are taken from the first six waves of the European Community Household Panel (ECHP), 1994-99. The ECHP is a survey based on a standardized questionnaire administered annually to a representative panel of households and individuals in 15 member states and offers detailed information on the respondent's labor market experience, inter al. (see, for example, EUROSTAT, 1999). ${ }^{1}$ We used data for thirteen of the countries: Austria, Belgium, Denmark, Finland, France, Germany, Greece, Ireland, Italy, Portugal, Spain, the Netherlands, and the United Kingdom. The excluded 
countries are Sweden and Luxembourg, where it is not possible to follow individuals through time. Data is not available for the entire period for five countries. Specifically, Austria and Finland were only added to the panel in 1995 and 1996; the data for Germany and the United Kingdom are for the first three waves alone because of missing data on reservation wages and job offers, respectively, in subsequent waves; and for the Netherlands information on reservation wages was missing for the years 1994 and 1995.

For us the key pieces of information contained in the EHCP are reservation wages, unemployment duration, and job offer rates. In the EHCP every individual actively looking for work is asked two questions pertaining first to desired hours of work and second to the minimum income required to work these hours. The actual questions are: “Assuming you could find suitable work, how many hours would you prefer to work in this new job?" and "What is the minimum net monthly income would you accept to work [these number of] hours a week in this new job?” The key reservation wage construct used in this paper is an hourly net reservation wage, computed as the ratio of desired net monthly income to the optimal number of hours. This variable was deflated by the respective national consumer price index, as were all other nominal arguments.

The measure of unemployment duration is strictly length of the jobless spell. For those actively seeking employment we know both the month and year of the interview ${ }^{2}$ as well as the date on which the previous job was lost. The difference in months is a measure of joblessness since it may include intervals of inactivity.

Finally, as far as the measure of job offers is concerned, the EHCP inquires of those seeking employment whether or not they had received a job offer in the previous month; specifically, “Have you received any job offer during the past 4 weeks?” We use this information on the receipt (and rejection) of job offers to proxy the arrival rate of 
job offers. According to the model, reservation wages should be increasing in the arrival rate of job offers.

\section{Findings}

First consider the determinants of reservation wages. Table 1 focuses on the role of unemployment insurance benefits and job offers. Two sets of OLS results are provided in the table according to whether the unemployment benefits variable is measured in terms of access to benefits or the amount of benefits received. The first (and second) column(s) refer to a specification containing an unemployment benefits dummy whereas the fourth (and fifth) column(s) refer to results from using the actual log level of benefits, each in conjunction with a job offers dummy variable indicating whether or not the unemployed individual received any offer of employment in the preceding four weeks. Each equation also includes a gender dummy, five time dummies, three schooling, and four age dummies.

(Table 1 near here)

It can be seen that the coefficient estimate for the unemployment benefits dummy is positive and well determined for five countries in the sample. For these countries - Denmark, the Netherlands, Greece, Portugal, and Spain - the effect on reservation wages of access to benefits is quite strong. For its part, the impact of having received a job offer is typically positive as one would anticipate - although this has not been demonstrated before - and in six cases is statistically significant. When benefits are expressed in monthly values, their influence is statistically significant in six cases (albeit not necessarily for the same countries). In this case, however, the elasticities are typically small. The principal exception is the United Kingdom where a 10 percent 
increase in benefit levels elevates reservation wages by 4 percent. Now the effect of job offers is much attenuated.

We next exploit the longitudinal capacity of our dataset to informally inquire into the course of reservation wages over jobless duration. To this end, the log hourly reservation wage is regressed on the log of elapsed jobless duration for an unbalanced panel of unemployed workers. This procedure should be thought of as a strictly descriptive exercise because of potential simultaneity. That is to say, reservation wages influence duration with certainty, but they may themselves also be influenced by duration.

(Table 2 near here)

Abstracting from simultaneity issues, Table 2 presents fixed and random effects specifications of the reservation wage equation, where the latter account for crosssection variation over the sample period. For the fixed effects specification in the second column of the table - which provides a meaningful control for individual heterogeneity - the coefficient estimates for jobless duration are statistically significant for just one country in the sample: Spain. And even here the coefficient estimate is very small and is only marginally significant. There is slightly greater evidence of a negative association between duration and reservation wages from the random effects specification, where we observe well-determined negative associations for Austria, Portugal, and (again) Spain. That said, the more important point is that reservation wages seem to be stationary for the large majority of countries, consistent with the basic search model if not with the early literature surveyed in Devine and Kiefer (1991). 


\section{Conclusions}

In this paper we have exploited a cross-country dataset - the European Community Household Panel (ECHP) - to examine directly (some aspects of) the role of reservation wages in the job search model. This is something of a new departure insofar as reservation wages are typically identified indirectly through theoretical and auxiliary restrictions. It is only something of a new departure, however, because other studies have also looked at direct evidence on reservation wages in individual countries. Our treatment differs from that sub-literature not simply in its cross-country basis but also with respect to its findings.

We have seen that both receipt and higher levels of unemployment insurance benefits translate into higher reservation wages, even if some of the point estimates are not statistically significant and the computed elasticities are quite small. The muted nature of the latter might indicate that there is not enough variation of replacement rates within countries. We have also uncovered for the first time the positive impact of the arrival rate of job offers on reservation wages.

Finally, again consistent with the basic model, we report that there is scant evidence of a decline in reservation wages with longer joblessness (see also Prasad, 2003). Indeed, the reservation wage appears stationary. The fact that reservation wages appear to be constant is interesting in itself, and may explain why unemployment rates are higher in Europe. Long (and in some cases near-lifetime) maximum duration of benefits may lie at the root of the problem. 


\section{Endnotes}

1. In 1994 for example some 60,500 such households, or a little over 130,000 adults aged 16 years and above, were interviewed.

2. Other than for Germany, where we assume it to be October in each year.

3. We exclude those individuals who reported receiving an offer and who also responded in the affirmative to a question in the survey indicating that they had accepted this offer. As a practical matter, however, this exclusion did not materially alter the results reported in Table 1.

4. If, however, reservation wages are constant, the endogeneity problem is no longer an issue. 


\section{References}

Bloemen, Hans and Elena Stancanelli (2001). "Individual Wealth, Reservation Wages, and Transitions into Employment.” Journal of Labor Economics 19 (April): 400-439.

Devine, Theresa J., and Nicholas M. Kiefer (1991). Empirical Labor Economics - The Search Approach. New York and Oxford: Oxford University Press.

EUROSTAT, 1999. European Community Household Panel. Longitudinal Users' Database. Waves 1, 2 and 3. Manual. Luxembourg: EUROSTAT.

Mortensen, Dale T. 1977. "Unemployment Insurance and Job Search Decisions." Industrial and Labor Relations Review 30 (July): 505-517.

Prasad, Eswar (2003). "What Determines the Reservation Wages of Unemployed Workers? New Evidence from German Micro Data.” IZA Discussion Paper No. 694, June. 
Table 1 The Determinants of Reservation Wages: The Effect of Unemployment Insurance Benefits and Job Offers

Recipient sample

Full sample

Job offer (dummy) Sample size

Country

Unemployment benefits (dummy)

Job offer (dummy)

Sample size

Unemployment benefits (log of amount)

size

\begin{tabular}{|c|c|c|c|c|c|c|}
\hline Germany & $\begin{array}{c}0.028 \\
(0.024)\end{array}$ & $\begin{array}{c}0.072 * * \\
(0.035)\end{array}$ & 862 & & & \\
\hline Denmark & $\begin{array}{c}0.110 * * * \\
(0.033)\end{array}$ & $\begin{array}{c}0.041 \\
(0.029)\end{array}$ & 1124 & $\begin{array}{c}0.056 \\
(0.039)\end{array}$ & $\begin{array}{c}0.031 \\
(0.041)\end{array}$ & 645 \\
\hline The Netherlands & $\begin{array}{c}0.078 * * * \\
(0.026)\end{array}$ & $\begin{array}{l}-0.004 \\
(0.040)\end{array}$ & 787 & $\begin{array}{c}0.090 * * * \\
(0.033)\end{array}$ & $\begin{array}{l}-0.020 \\
(0.087)\end{array}$ & 158 \\
\hline Belgium & $\begin{array}{l}-0.035 \\
(0.024)\end{array}$ & $\begin{array}{c}0.017 \\
(0.026)\end{array}$ & 1090 & $\begin{array}{c}0.070 * * * \\
(0.017)\end{array}$ & $\begin{array}{c}0.012 \\
(0.030)\end{array}$ & 847 \\
\hline France & $\begin{array}{c}0.013 \\
(0.008)\end{array}$ & $\begin{array}{c}0.026^{* *} \\
(0.012)\end{array}$ & 3947 & $\begin{array}{c}0.125 * * * \\
(0.010)\end{array}$ & $\begin{array}{c}0.001 \\
(0.020)\end{array}$ & 1598 \\
\hline United Kingdom & $\begin{array}{c}0.056 \\
(0.032)\end{array}$ & $\begin{array}{l}-0.070 \\
(0.068)\end{array}$ & 934 & $\begin{array}{c}0.391^{* * * *} \\
(0.157)\end{array}$ & $\begin{array}{l}-0.254 \\
(0.229)\end{array}$ & 169 \\
\hline Ireland & $\begin{array}{l}-0.008 \\
(0.018)\end{array}$ & $\begin{array}{c}0.124 * * * \\
(0.035)\end{array}$ & 1751 & $\begin{array}{c}0.170^{* * *} \\
(0.050)\end{array}$ & $\begin{array}{c}0.240 * * \\
(0.100)\end{array}$ & 214 \\
\hline Italy & $\begin{array}{l}-0.004 \\
(0.023)\end{array}$ & $\begin{array}{c}0.014 \\
(0.021)\end{array}$ & 6689 & $\begin{array}{c}0.035 \\
(0.025)\end{array}$ & $\begin{array}{c}0.184 \\
(0.132)\end{array}$ & 130 \\
\hline Greece & $\begin{array}{c}0.033^{* *} \\
(0.014)\end{array}$ & $\begin{array}{l}0.063 * \\
(0.033)\end{array}$ & 3387 & $\begin{array}{c}0.022 \\
(0.044)\end{array}$ & $\begin{array}{c}0.026 \\
(0.111)\end{array}$ & 301 \\
\hline Spain & $\begin{array}{c}0.090 * * * \\
(0.009)\end{array}$ & $\begin{array}{c}0.038 * * \\
(0.016)\end{array}$ & 6975 & $\begin{array}{c}0.191 * * * \\
(0.026)\end{array}$ & $\begin{array}{c}0.062 \\
(0.038)\end{array}$ & 955 \\
\hline Portugal & $\begin{array}{c}0.039 * * \\
(0.015)\end{array}$ & $\begin{array}{c}0.115^{* *} \\
(0.047)\end{array}$ & 2051 & $\begin{array}{c}0.280 * * * \\
(0.035)\end{array}$ & $\begin{array}{c}0.088 \\
(0.157)\end{array}$ & \\
\hline Austria & $\begin{array}{c}0.060 \\
(0.063)\end{array}$ & $\begin{array}{c}0.047 \\
(0.065)\end{array}$ & 514 & $\begin{array}{c}0.140 \\
(0.176)\end{array}$ & $\begin{array}{l}-0.025 \\
(0.124)\end{array}$ & 158 \\
\hline Finland & $\begin{array}{c}0.017 \\
(0.054)\end{array}$ & $\begin{array}{l}-0.002 \\
(0.080)\end{array}$ & 1582 & $\begin{array}{c}0.035 \\
(0.023)\end{array}$ & $\begin{array}{l}-0.024 \\
(0.097)\end{array}$ & 842 \\
\hline
\end{tabular}

Standard errors in parentheses

$* * *, * *$, and $*$ denote statistical significance at the $.01, .05$, and .10 levels

Note: The regressions include a gender dummy and 3 schooling, 4 age, and 5 time dummies. 
Table 2 Estimates of the Impact of (Log) Duration on Reservation Wages Using Longitudinal Data

Random effects $\quad$ Fixed effects

\section{Country}

\begin{tabular}{|c|c|c|c|}
\hline Germany & $\begin{array}{l}-0.007 \\
(0.011)\end{array}$ & $\begin{array}{c}0.019 \\
(0.018)\end{array}$ & 613 \\
\hline Denmark & $\begin{array}{l}-0.002 \\
(0.007)\end{array}$ & $\begin{array}{c}0.018 \\
(0.013)\end{array}$ & 1303 \\
\hline The Netherlands & $\begin{array}{l}-0.014 \\
(0.011)\end{array}$ & $\begin{array}{c}0.018 \\
(0.030)\end{array}$ & 421 \\
\hline Belgium & $\begin{array}{c}0.000 \\
(0.008)\end{array}$ & $\begin{array}{c}0.001 \\
(0.015)\end{array}$ & 837 \\
\hline France & $\begin{array}{l}-0.004 \\
(0.005)\end{array}$ & $\begin{array}{c}0.001 \\
(0.009)\end{array}$ & 2085 \\
\hline United Kingdom & $\begin{array}{c}0.006 \\
(0.010)\end{array}$ & $\begin{array}{l}-0.039 \\
(0.033)\end{array}$ & 839 \\
\hline Ireland & $\begin{array}{l}-0.008 \\
(0.137)\end{array}$ & $\begin{array}{l}-0.015 \\
(0.010)\end{array}$ & 1583 \\
\hline Italy & $\begin{array}{l}-0.005 \\
(0.004)\end{array}$ & $\begin{array}{l}-0.004 \\
(0.008)\end{array}$ & 4814 \\
\hline Greece & $\begin{array}{l}-0.013 \\
(0.006)\end{array}$ & $\begin{array}{l}-0.016 \\
(0.012)\end{array}$ & 1855 \\
\hline Spain & $\begin{array}{c}-0.008 * * * \\
(0.003)\end{array}$ & $\begin{array}{l}-0.009 * \\
(0.005)\end{array}$ & 5861 \\
\hline Portugal & $\begin{array}{c}-0.011^{*} \\
(0.006)\end{array}$ & $\begin{array}{c}0.000 \\
(0.009)\end{array}$ & 1639 \\
\hline Austria & $\begin{array}{c}-0.028 * * \\
(0.014)\end{array}$ & $\begin{array}{l}-0.008 \\
(0.059)\end{array}$ & 621 \\
\hline Finland & $\begin{array}{l}-0.003 \\
(0.006)\end{array}$ & $\begin{array}{l}-0.001 \\
(0.008)\end{array}$ & 1683 \\
\hline
\end{tabular}

Standard errors in parentheses

$* * *, * *$, and $*$ denote statistical significance at the $.01, .05$, and .10 levels

Note: The regressions include a gender dummy and 3 schooling, 4 age, and 5 time dummies. 